\title{
Metazoan parasites of fish species from Lake Gala (Edirne, Turkey)
}

\section{Gala Gölü (Edirne)' ndeki balık türlerinin metazoan parazitleri}

\section{Erhan Soylu}

Fisheries Department, Vocational School of Technical Sciences, Marmara University, Göztepe, TR-34722 Kadıköy, İstanbul esoylu@marmara.edu.tr

\author{
How to cite this paper: \\ Soylu, E., 2014. Metazoan parasites of fish species from Lake Gala (Edirne, Turkey). Ege J Fish Aqua Sci 31(4): 187-193. \\ doi: 10.12714 /egejfas.2014.31.4.03
}

Özet: Türkiye'nin kuzey-batısında yer alan öytrofik özellikteki Gala Gölü balıklarının parazitleri bilinmemektedir, bu nedenle araştırmamızda gölde bulunan balıkların metazoan parazitleri araştırımıştır. Temmuz 2010 ve Haziran 2011 tarihleri arasında Gala Gölü’nde bulunan 16 balık türünden toplam 497 örnekle çalışıldı. Bu balıklarda 53 metazoan parazit türü teşhis edildi. Bu parazitlerden 32 Monogenea, 4 Cestoda, 7 Digenea, 4 Acanthocephala, 3 Nematoda, 2 Copepoda ve 1 Mollusca (glochidia) türü kaydedildi. Gala Gölü'nde incelenen balıkların parazit topluluğunun yapısı \%34.0 endoparazit ve \%66.0 ektoparazitlerden oluşmaktadır. Çalışılan tüm balık türlerindeki en yaygın parazit türleri; monogenean türler, Diplostomum spp., Tylodelphys clavata ve glochidia larvasıdır. Monogenean türlerle en yüksek enfeksiyon yüzdesi Rutilus rutilus'ta (\%77.0) bulundu, Diplostomum spp. en yüksek yaygınlıkla Abramis brama'da (\%100) görüldü. En çok sayıda parazit türü, 10 türle Abramis brama'da ve dokuz türle Carassius gibelio'da bulundu. Bu makale Gala Gölü'ndeki balıkların parazitleriyle ilgili ilk çalışmadır.

Anahtar kelimeler: Metazoan, parazit, balık, Gala Gölü

Abstract: Eutrophic Lake Gala, located in the north-west of Turkey, fish parasites of the lake are unknown; therefore, in the present investigation the metazoan parasites of the resident fish were examined. A total of 497 specimens of 16 fish species inhabiting Lake Gala were examined between July 2010 and June 2011. In or on these fish, 53 metazoan parasite species were identified. From these parasites, 32 species of Monogenea, four species of Cestoda, seven species of Digenea, four species of Acanthocephala, three species of Nematoda, two species of Copepoda and one species of Mollusca (glochidia) were recorded. The parasite community structure of the examined fishes from Lake Gala was made up of $34.0 \%$ endoparasites and $66.0 \%$ ectoparasites. Monogenean species, Diplostomum spp., Tylodelphys clavata and glochidia larvae were the most prevalent parasite species in all the fish hosts examined. The highest prevalence of infection with monogenean species was found in Rutilus rutilus (prevalence $77.0 \%$ ); Diplostomum spp. occurred with the highest prevalence (100\%) in Abramis brama. The largest numbers of parasites species were found in Abramis brama (10 species) and Carassius gibelio (nine species). This paper represents the first study of parasites of the fishes in Lake Gala.

Keywords: Metazoan, parasite, fish, Lake Gala

\section{INTRODUCTION}

The Meriç Delta, where Lake Gala is located, has formed on an area of 45000 ha at the mouth of the Meriç River and qualifies as a class A International Wetland. The lake has been formed behind the embankments that have come into existence by sedimentary deposition of material by the Meriç River. Lake Gala consists of Big Gala and Small Gala, which are divided by a shallow threshold during the summer months. The total area of Lake Gala is $5.6 \mathrm{~km}^{2}$ and it has an average depth of $1.20 \mathrm{~m}$. The water that feeds the lake amounts to $198.7 \mathrm{hm} 3 /$ year; most (90.3\%) of this water comes from paddy fields around the Lake (Zal, 2006) and influences water quality. Lake Gala, which was registered as a wetland protected field and declared to be National Park in 2005, is on the route of migrant birds and is a breeding area of native and migrant birds. According to Kaya and Kurtonur, (2003), 134 bird species inhabit the lake including fish-eating birds. Of these bird species, 29 are residents, 64 summer migrants, 26 winter migrants and 20 breed in the lake.

Some studies have been performed on Lake Gala. Ortak and Kırgız, (1988) investigated Cladocera and Copepoda species. Kırgız, (1988) studied Chironomidae (Diptera) larvae. Limnological features of the lake were studied by Baran and Ongan, (1988). Kaya and Kurtonur (2003) studied the ornithofauna of the lake and its surroundings. Özuluğ et al., (2004) reported on Carassius gibelio from the Lake. Erdoğan and Güher, (2005) investigated rotifer fauna. A study on the implementation of the lower Meriç Valley was performed by Zal, (2006). A study on associated microcrustacea (Cladocera, Copepoda) with macrophytes in Lake Gala was performed by Güher and Kırgız, (2007). Çamur-Elipek et al., (2008) studied physico-chemical characteristics and benthic macroinvertebrates. Çamur-Elipek et al., (2010) studied 
benthic invertebrates in relation to environmental variables. However, there has been no investigation on parasites of fish species of Lake Gala. Consequently, the aim of the present study was carried out to report on the metazoan parasites of the fish species in this lake. This is the first record of metazoan fish parasites from Lake Gala.

\section{MATERIALS AND METHOD}

The fish specimens were taken from July 2010 to June 2011 from Lake Gala (40 46' 60" N, 26 11' 64" E). Fish samples were collected four times in July, October, January and April as seasonally from local fishermen. In total, 497 fish specimens were examined: 49 roach (Rutilus rutilus), 71 gibel carp (Carassius gibelio), 63 rudd (Scardinius erytrophthalmus), three white bream (Blicca bjoerkna), 38 carp bream (Abramis brama), 18 carp (Cyprinus carpio), 13 asp (Aspius aspius), 15 vimba (Vimba vimba), 64 European perch (Perca fluviatilis), seven zander (Sander lucioperca), 87 pumpkinseed (Lepomis gibbosus), five eel (Anguilla anguilla), nine pike (Esox lucius), five cat fish (Silurus glanis), 42 striped mullet (Mugil cephalus) and eight twaite shad (Alosa fallax). The fish were transported to the laboratory alive, where they were all weighed, measured and their sex determined. Dissection of the fish was made within two days. During the dissection, the body cavity, all internal organs, the gills, the eyes (lens and vitreous humour), the skin and the fins were examined. Prevalence and mean intensity were calculated according to Margolis et al., (1982). Parasites recovered were fixed and preserved according to Bylund et al., (1980). Identification of parasites was made according to Niewiadomska (2003), Scholz et al., (1998), Pugachev et al., (2010) and Bykhovskaya-Pavlovskaya et al., (1962)

\section{RESULTS}

A total of 497 specimens of fish hosts belonging to 16 species were examined and 53 parasite species relating to seven higher taxa (Monogenea, Cestoda, Digenea, Acanthocephala, Nematoda, Mollusca and Crustacea) recorded. A list of the 53 parasite species found in the fish hosts examined from the Lake is shown in Table 1. The parasite community structure of the fishes from Lake Gala was made up of $34.0 \%$ endoparasites and $66.0 \%$ ectoparasites. The monogenean species belonging to Dactylogyridae, Ancyrocephalidae, Pseudodactylogyridae, Tetraonchidae, Gyrodactylidae and Diplozoidae were the most prevalent parasites, infesting 14 host species. Diplostomum spp. metacercariae was the second most prevalent parasite, infecting 12 host species. Other highly prevalent parasite species were Tylodelphys clavata metacercariae and glochidia larvae, both infecting nine host species. Copepod parasites were recorded on the gills of only one marine fish species (Mugil cephalus). Caryophyllaeus fimbriceps was found only in the intestine of Carassius gibelio. Abramis brama and $C$. gibelio exhibited rich parasite biodiversity, with 10 and nine species, respectively. Rutilus rutilus, Scardinius erythrophthalmus, Vimba vimba, Lepomis gibbosus and Anguilla anguilla harboured eight parasite species. The number of parasite species that all other fish host harbours were; Perca fluviatilis seven, Cyprinus carpio six, Sander lucioperca three, Silurus glanis two, Esox lucius six, Blicca bjoerkna two, Aspius aspius five, M. cephalus six and Alosa fallax two (Table 1). Perca fluviatilis has the highest number of core parasite species, with four species. The number of core parasite species was different for each fish host. The prevalence and mean intensity of the most prevalent parasite species for seven extensively studied fish hosts are shown in Table 2. Pictures of important features for the identification of some parasites found in the present study is shown in Figures $1-6$

Table 1. Parasite species and their fish hosts recorded in Lake Gala

\begin{tabular}{ll}
\hline Parasite species & \\
\hline METAZOA & \\
Platyhelminthes & \\
Monogenea & \\
DACTYLOGYRIDAE & \\
Dactylogyrus difformis Wagener, 1857 & S. erytrophthalmus \\
Dactylogyrus difformoides Glaser and Gussev, 1967 & S. erytrophthalmus \\
Dactylogyrus crucifer Wagener, 1857 & R. rutilus \\
Dactylogyrus anchoratus (Dujardin, 1845) & C. gibelio \\
Dactylogyrus vastator Nybelin, 1924 & C. gibelio \\
Dactylogyrus cornu Linstow, 1878 & R. rutilus \\
Dactylogyrus cornoides Glaser and Gussev, 1971 & R. rutilus \\
Dactylogyrus vistulae Prost, 1957 & R. rutilus \\
Dactylogyrus distinguendus Nybelin, 1937 & A. brama \\
Dactylogyrus baueri Gussev, 1955 & C. gibelio \\
Dactylogyrus inexpectatus Isjumova in Gussev, 1955 & C. gibelio \\
Dactylogyrus extensus Mueller and Van Cleave, 1932 & C. carpio \\
Dactylogyrus auriculatus (Nordmann, 1832) & A. brama \\
Dactylogyrus zandti Bychowsky, 1933 & A. brama \\
Dactylogyrus wunderi Bychowsky, 1931 & A. brama \\
Dactylogyrus haplogonoides Gussev, 1966 & V. vimba
\end{tabular}


Dactylogyrus sphyrna Linstow, 1878

Dactylogyrus tuba Linstow, 1878

Dactylogyrus sp.

\section{ANCYROCEPHALIDAE}

Ancyrocephalus paradoxus Creplin, 1839

Thaparocleidus siluri (Zandt, 1924)

Thaparocleidus vistulensis (Siwak, 1932) Limi 1996

Urocleidus similis (Mueller, 1936)

Ligophorus sp. I

Ligophorus sp. II

\section{PSEUDODACTYLOGYRIDAE}

Pseudodactylogyrus anguillae (Yin and Sproston, 1948)

Pseudodactylogyrus bini (Kikuchi, 1929)

TETRAONCHIDAE

Tetraonchus monenteron (Wagener, 1857)

GYRODACTYLIDAE

Gyrodactylus sp. I

Gyrodactylus sp. II

DIPLOZOIDAE

Paradiplozoon pavlovski (Bychowsky and Nagibina, 1959)

Paradiplozoon sp.

\section{Cestoda}

\section{CARYOPHYLLIDAE}

Caryophyllaeus fimbriceps Annenkova-Khlopina, 1919

\section{BOTHRIOCEPHALIDAE}

Bothriocephalus claviceps (Goeze, 1782)

Bothriocephalus acheilognathi Yamaguti, 1934

PROTEOCEPHALIDAE

Proteocephalus percae (Müller, 1780)

\section{Digenea}

DIPLOSTOMATIDAE

Diplostomum spp.

Posthodiplostomum cuticola (Nordmann, 1832)

Tylodelphys clavata (Nordmann, 1832)

\section{CLINOSTOMATIDAE}

Clinostomum complanatum Rudolphi, 1814

Digenea gen. sp. I

Digenea gen. sp. II

Digenea gen. sp II

Acanthocephala

Acanthocephalus lucii (Müller, 1777)

Acanthocephalus anguillae (Müller, 1780)

Acanthocephalus sp.

\section{NEOECHINORHYNCHIDAE}

Neoechinorhynchus sp.

Nematoda

\section{DIOCTOPHYMATIDAE}

Eustrongylides excisus Jagerskiöld, 1909

\section{DRACUNCULIDAE}

Anguillicoloides crassus (Kuwahara, Niimi and Itagaki, 1974)

Nematod gen. sp

\section{Copepoda}

\section{ERGASILIDAE}

Ergasilus lizae Kroyer, 1863

LERNAEIDAE

Lernaea cyprinacea Linnaeus, 1758

Mollusca

Bivalvia

UNIONIDAE

Glochidia (larvae)
$R$. rutilus

A. aspius

V. vimba

S. lucioperca

S. glanis

S. glanis

L. gibbosus

M. cephalus

M. cephalus

A. anguilla

A. Anguilla

E. lucius

S. erytrophthalmus

C. gibelio

\section{A. aspius}

C. carpio

C. gibelio

A. anguilla

C. carpio, P. fluviatilis

P. fluviatilis

$S$. erythrophthalmus, $R$. rutilus, L. gibbosus,

A. aspius, C. gibelio, C. carpio, M. cephalus,

$E$. lucius, $A$. brama, $P$. fluviatilis, $V$. vimba,

A. anguilla

S. erythrophthalmus, V. vimba

$R$. rutilus, L. gibbosus, C. gibelio, C. carpio,

E. lucius, $S$. erythrophthalmus, A. brama, $P$.

fluviatilis, V. vimba

P. fluviatilis, S. erythrophthalmus, $R$. rutilus

A. fallax

A. fallax

M. cephalus

A. anguilla

A. anguilla, $P$ fluviatilis

L. gibbosus, $P$. fluviatilis

E. lucius

P. fluviatilis, $L$. gibbosus

A. anguilla

L. gibbosus

M. cephalus, A. fallax

L. gibbosus

R. rutilus, L. gibbosus, $A$. anguilla, $A$.

aspius, $C$. gibelio, $M$. cephalus, $S$

erytrophthalmus, $A$. brama, $P$. fluviatilis 
Table 2. Prevalence (P; \%) and mean intensity (MI) of metazoan parasites from some fish species in Lake Gala.

\begin{tabular}{|c|c|c|c|c|c|c|c|c|c|c|c|c|c|c|}
\hline \multirow{2}{*}{$\begin{array}{l}\text { Fish } \\
\text { Parasites }\end{array}$} & \multicolumn{2}{|c|}{$\begin{array}{l}\text { Lepomis } \\
\text { gibbosus }\end{array}$} & \multicolumn{2}{|c|}{$\begin{array}{l}\text { Carassius } \\
\text { gibelio }\end{array}$} & \multicolumn{2}{|c|}{$\begin{array}{l}\text { Scardinius } \\
\text { erythrophthalmus }\end{array}$} & \multicolumn{2}{|c|}{$\begin{array}{l}\text { Perca } \\
\text { fluviatilis }\end{array}$} & \multicolumn{2}{|c|}{ Rutilus rutilus } & \multicolumn{2}{|c|}{$\begin{array}{l}\text { Abramis } \\
\text { brama }\end{array}$} & \multicolumn{2}{|c|}{ Mugil cephalus } \\
\hline & $\begin{array}{l}P \\
(\%)\end{array}$ & MI & $\begin{array}{l}P \\
(\%)\end{array}$ & MI & $\begin{array}{l}P \\
(\%)\end{array}$ & MI & $\begin{array}{l}P \\
(\%)\end{array}$ & MI & $\begin{array}{l}P \\
(\%)\end{array}$ & MI & $\begin{array}{l}P \\
(\%)\end{array}$ & MI & $\begin{array}{l}P \\
(\%)\end{array}$ & MI \\
\hline $\begin{array}{l}\text { Monogenea } \\
\text { Cestoda }\end{array}$ & 60.0 & - & 59.9 & - & 34.4 & - & - & - & 77.0 & - & 50.0 & - & 16.6 & - \\
\hline Bothriocephalus sp. & 3.3 & 2.0 & 6.6 & - & - & - & - & - & - & - & - & - & - & - \\
\hline $\begin{array}{l}\text { Proteocephalus percae } \\
\text { Digenea }\end{array}$ & - & - & - & - & - & - & 38.5 & 7.6 & - & - & - & - & - & - \\
\hline Diplostomum sp. & 60.0 & 1.9 & 26.6 & 1.2 & 55.2 & 7.0 & 19.2 & 1.0 & 84.6 & 33.6 & 100.0 & 13.9 & 16.6 & 8.6 \\
\hline Tylodelphys clavata & 43.3 & 2.7 & 6.6 & 2.0 & 24.1 & 22.1 & 88.5 & 100.6 & 84.6 & 37.8 & 75.0 & 11.8 & - & 8.0 \\
\hline $\begin{array}{l}\text { Posthodiplostomum } \\
\text { cuticula }\end{array}$ & - & - & - & - & 31.0 & 17.3 & - & - & 30.8 & 7.2 & 8.3 & 13.8 & - & - \\
\hline $\begin{array}{l}\text { Clinostomum } \\
\text { complanatum }\end{array}$ & - & - & - & - & 17.2 & 1.8 & 53.8 & 2.4 & 7.7 & 4.0 & - & - & - & - \\
\hline Nematoda & 23.3 & 1.0 & - & - & - & - & 84.6 & 13.9 & - & - & - & - & - & - \\
\hline Acanthocephala & 3.3 & 2.0 & - & - & - & - & 34.6 & 3.9 & - & - & - & - & - & - \\
\hline Copepoda & 10.0 & 1.3 & - & - & - & - & - & - & - & - & - & - & 25.0 & 2.3 \\
\hline Mollusca & 63.3 & 6.1 & 13.3 & 19.0 & 58.6 & 20.3 & 69.2 & 18.1 & 7.7 & 12.0 & 16.6 & 20.1 & 50.0 & 3.7 \\
\hline
\end{tabular}
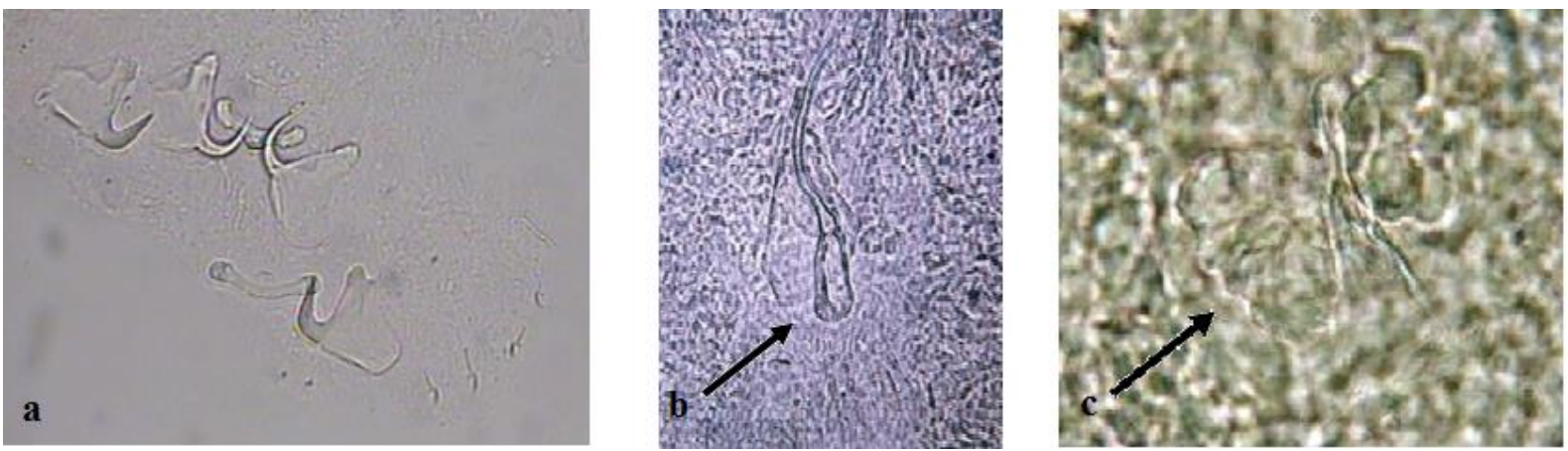

Figure 1. Ancyrocephalus paradoxus a. anchors, marginal hooks, b. copulatory organ, c. vaginal tube.
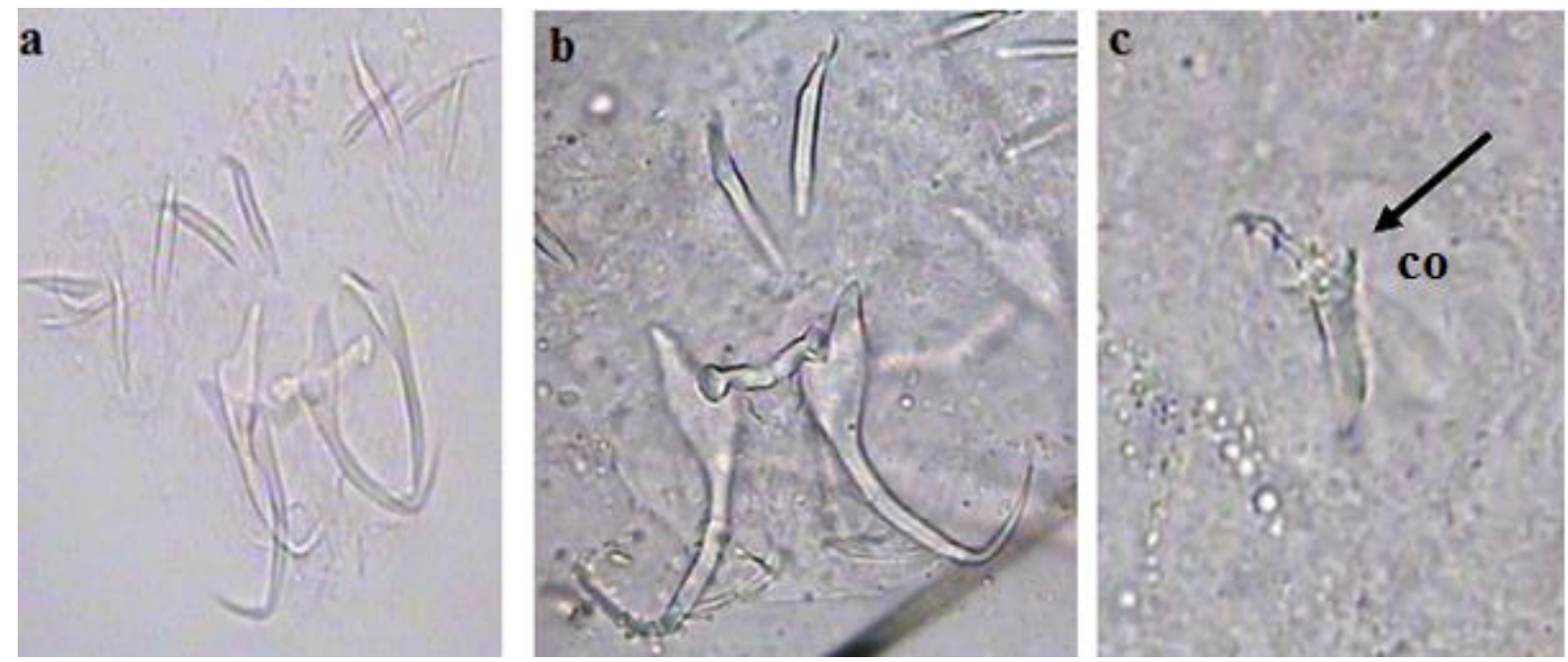

Figure 2. Urocleidus similis a-b. anchors, marginal hooks, c. copulatory organ. 

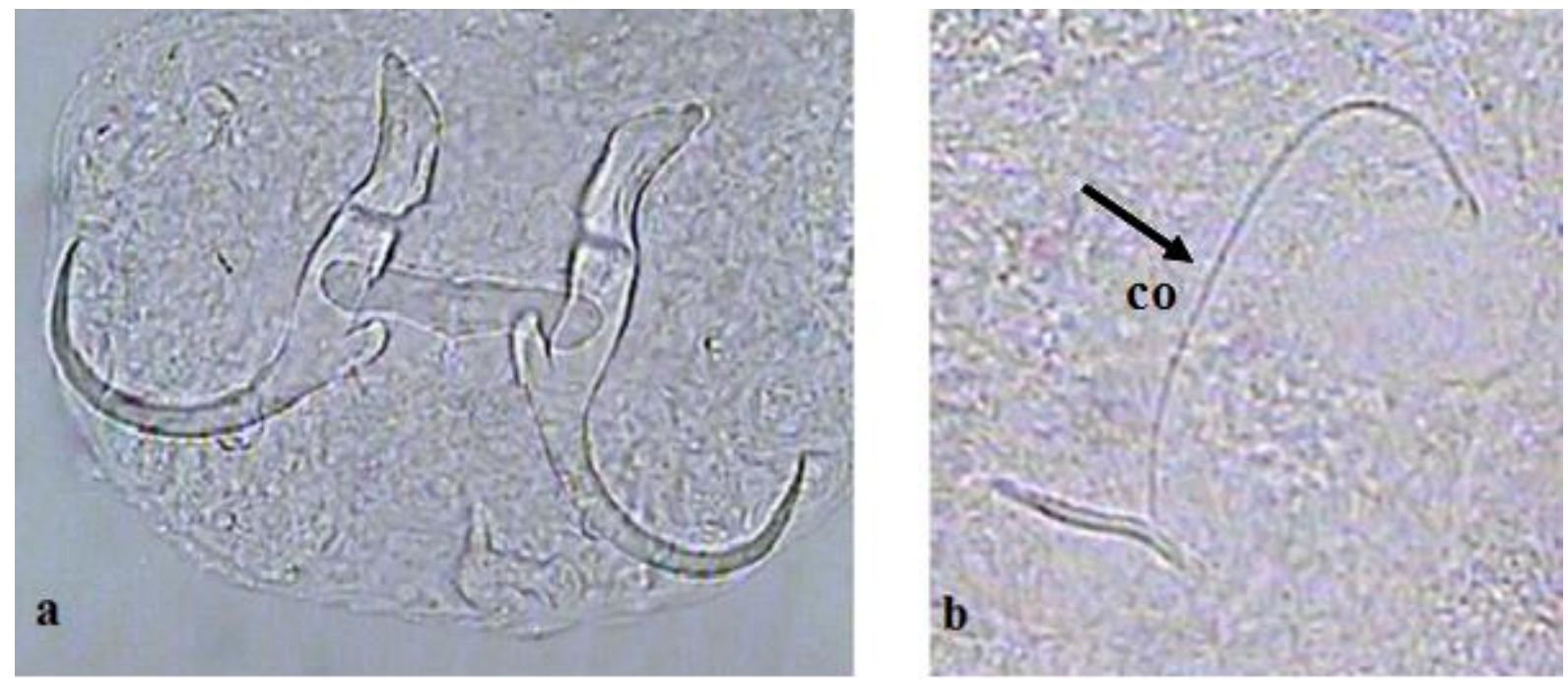

Figure 3. Pseudodactylogyrus anguillae a. median anchors, b. copulatory organ.
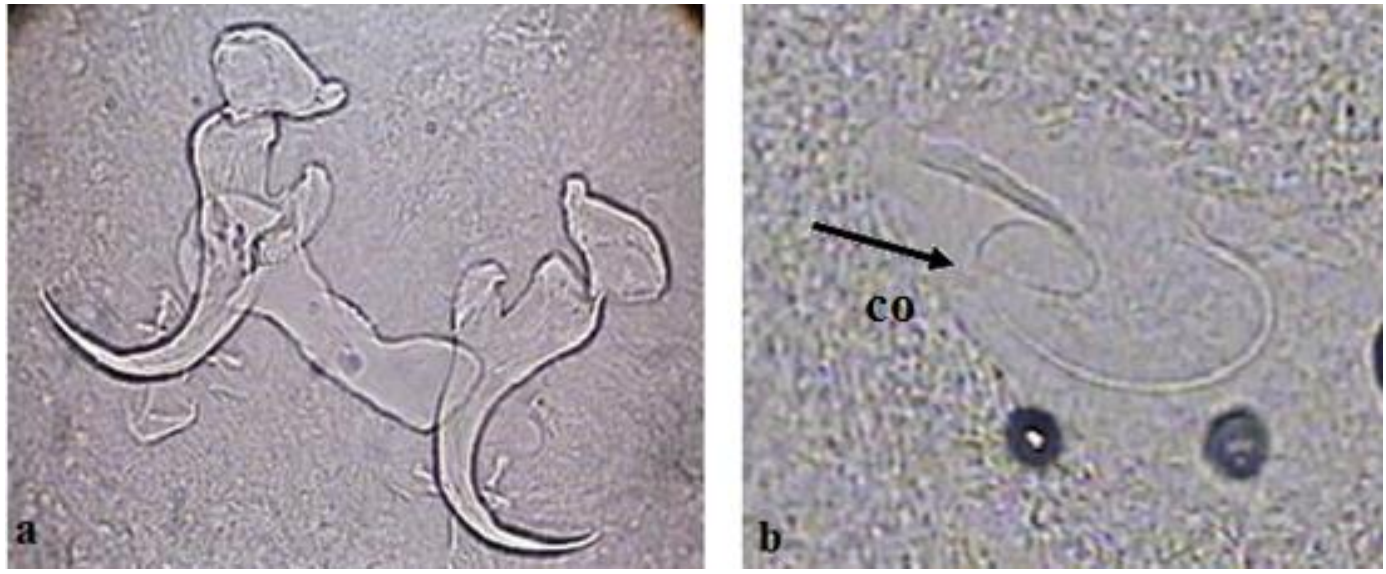

Figure 4. Pseudodactylogyrus bini a. median anchors, b. copulatory organ.
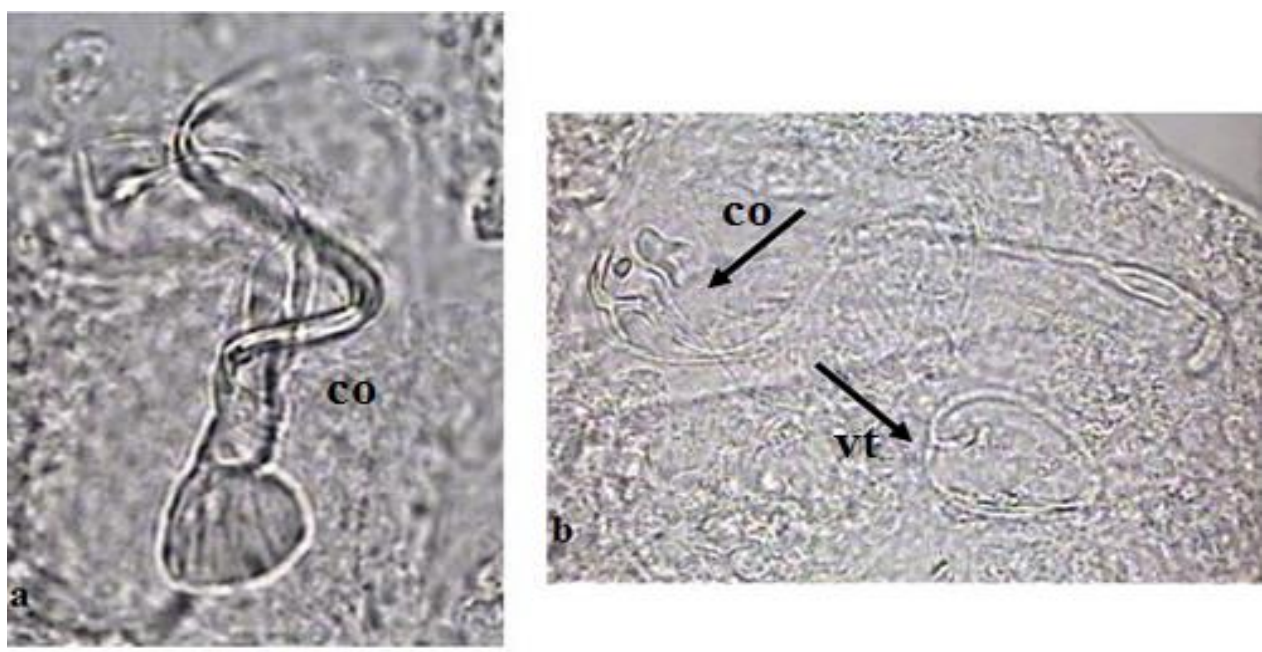

Figure 5.. a.Dactylogyrus haplogonoides copulatory organ, b. Dactylogyrus auriculatus copulatory organ and vaginal tube. 

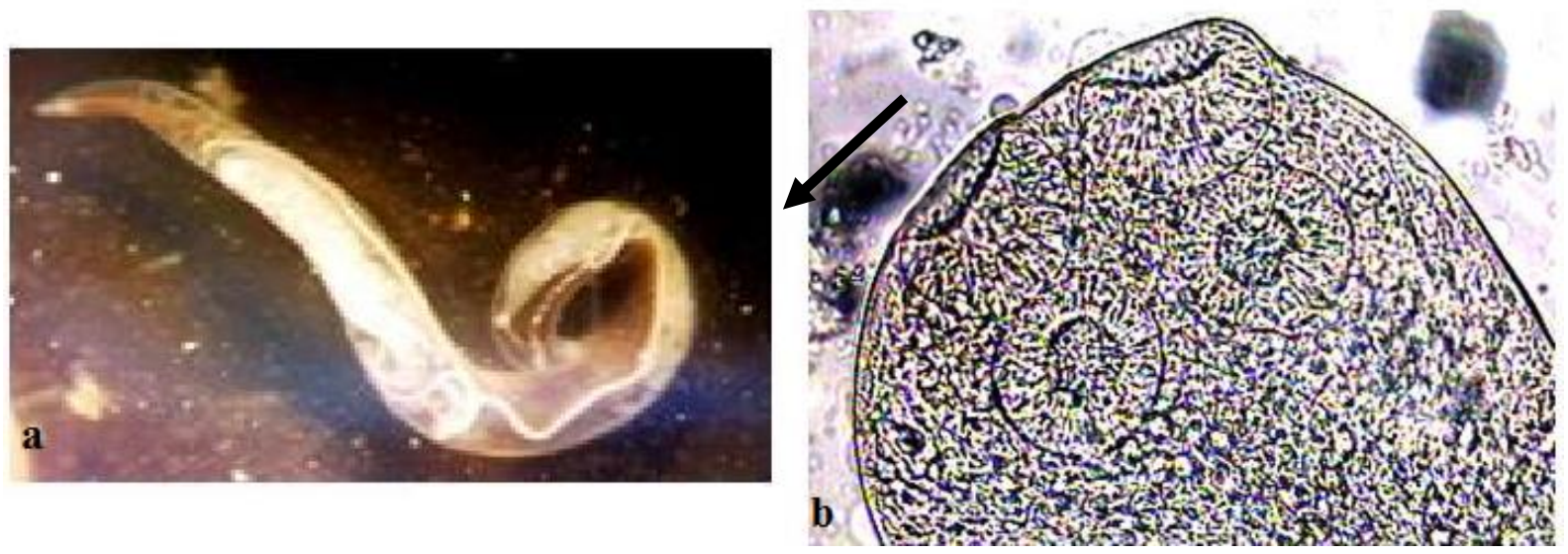

Figure 6. a. Anguillicoloides crassus, b. Proteocephalus percae head and four suckers.

The potential parasite number in Anguilla anguilla, Aspius aspius, Cyprinus carpio, Esox lucius, Silurus glanis, Bilicca bjoerkna, Vimba vimba, Alosa fallax and Sander lucioperca is probably greater than mentioned here because of the few specimens that were examined.

\section{DISCUSSIONS}

Previous studies on Lake Gala have determined its trophic status (Baran and Ongan., 1988; Kırgız, 1988; Ortak and Kırgız, 1988; Erdoğan and Güher, 2005; Çamur-Elipek et al., 2008, 2010). Lake Gala can be termed as eutrophic regarding the rotifera species identified (Erdoğan and Güher, 2005). Paddy fields periodically use the lake water for irrigation; later on, remaining water is pumped back to the lake which is charged with chemicals (pesticides and fertilizers). Benthic fauna of the lake dominated by two groups (Chironomidae and Oligochaeta), which are known to be pollution-tolerant organisms (Çamur-Elipek et al., 2010). Pollutants are toxic both to fish and invertebrate hosts; furthermore there are direct effect of pollutants on parasites and their free-living stage (Poulin, 1992). Low benthic invertebrate richness and diversity, a high number of individual existence of some Chironomidae species (e.g., Chironomus plumosus) and some Oligochaeta species (e.g., Limnodrilus hoffmeisteri, Potamothrix hammoniensis) and also the existence of Orthocladiinae larvae (especially Cricotopus flavocinctus) are associated with eutrophic state. In the lake, Gastropoda (Unio sp., Viviparus sp. and Planorbiidae) were found to have the lowest prevalence $(2.8 \%)$ of all taxa (Çamur-Elipek et al., 2010). The presence of gastropods is important in the transmission of digenetic trematodes (Paperna, 1996). The findings of the present study show that the fish in Lake Gala have a poor community of intestinal endoparasites. The species composition of parasite communities is clearly affected by environmental stress, and species richness tends to decrease under degraded conditions. The fact that parasites possess complex life cycles makes them extremely valuable information units about environmental conditions, because their presence or absence indicates a great deal about not only their host ecology but also food web interactions, biodiversity and environmental stress (Overstreet, 1997; Marcogliese, 2004). Contamination of fresh water habitats affects the viability of the free-living transmission stage of helminth parasites of fish (Pietrock et al., 2001). Parasites with indirect life cycles that were recorded in this study were cestodes, digenetic trematodes, acanthocephalans and nematodes. Diplostomum sp. and Tylodelphys clavata metacercariae, were found to be the most prevalent digenean parasites in 12 and nine fish hosts respectively. Eustrongylides excisus, $T$. clavata and Clinostomum complanatum were also found as the core parasite species in perch. The intermediate host of E. excisus is aquatic tubificid oligochaetes, which is common on benthic fauna of the lake and is pollution tolerant; the definitive hosts of all these parasites are fish-eating birds. In total, 134 water birds inhabit Lake Gala and its surrounding area; Pelecanus onocrotalus, Cygnus olor, Phalacrocorax pygmeus, Egretta garzetta and Ardea cinerea are the dominant bird species (Kaya and Kurtonur, 2003). The relative abundance of endoand ectoparasites of fish in a particular aquatic system can be used as an indicator of environmental stress. Ectoparasites are more in contact with water; therefore, sensitive ectoparasites are fewer than endoparasites in a polluted system, while the converse is also true (Avenant-Oldewage, 2001). The highest monogenean abundance and diversity were found in a polluted lake than in an oligotrophic lake (Koskivaara and Valtonen, 1992). In the present study the overall prevalence of ectoparasites $(66.0 \%)$ was found higher than that of endoparasites (34.0\%).

Lake Gala has native freshwater, non-native and marine fish species by reason of natural connection with the Aegean Sea; therefore parasite biodiversity can also be related to these characteristics of the lake. Metazoan parasites, identified at the species level, consist of 18 specialists and 20 generalists, all of the specialist parasites belonging to monogenea. Other than Diplostomum spp., Tylodelphys clavata, Posthodiplostomum cuticola and Clinostomum complanatum, which are the most common parasites both for 
unpolluted and polluted environments, one digenetic trematode was found in the gut of Mugil cephalus and another two in the gut of Alosa fallax and both of these fish hosts are marine species.

In conclusion, 53 metazoan parasites were recorded from the fish of Lake Gala. The most dominant parasite species found on each fish species except Perca fluviatilis were the monogeneans, which have a direct life cycle. However, to exclude two digenean parasites found in marine fish species, only four parasite species have an indirect life cycle.

\section{REFERENCES}

Avenant-Oldewage A., 2001. Protocol for the assessment of fish health based on the Health Index. Report and manual for training of field workers to the Rand Water Board. Report no. 2001/03/31, BIOM. GEN. (H1) Rand Water, Vereeniging.

Baran, I., Ongan, T., 1988. Limnological Features of Lake Gala, Fisheries Problems and Suggestions (in Turkish). Gala Gölü ve Sorunlar Sempozyumu, Doğal Hayatı Koruma Derneği Bilimsel Yayınlar Serisi İstanbul, pp. 46-54.

Bykhovskaya-Pavlovskaya, IE., Gussev, AV., Dubinina, MN., Izyumova, NA. Simirnova, TS., Sokolovskaya, I., Shtein, GA., Shulman, S., Epshtein, VM., 1962. Key to parasites of freshwater fish of the USSR. Izdatelsv Akademi Nauk SSSR. Moskva Leningrad (Translated from Russian, Israel Program for Scientific Translation, Jerusalem).

Bylund, G., Fagerholm, HP., Calenius, G., Wikgren, B., Wikstöm, M., 1980 Parasites of fish in Finland II. Methods for studying parasite fauna in fish. Acta Academiae Aboensis Ser. B Vol. 40, Nr.2, 23 pp.

Çamur-Elipek, B., Kırgız, T., Güher, H., Arslan, N., Öterler, B., 2008. A preliminary study on some physico-chemical characteristics of Lake Gala and relation between planctonic organisms and benthic macroinvertebrates. Third National Limnology Symposium, Ege University-İzmir, 27-28 August 2008.

Çamur-Elipek, B., Arslan, N., Kırgız, T., Öterler, B., Güher, H., Özkan, N. 2010. Analysis of Benthic macroinvertebrates in relation to environmental variables of Lake Gala, a national park of Turkey. Turkish Journal of Fisheries and Aquatic Sciences, 10: 235-243 doi: 10.4194/trjfas.2010.0212

Erdoğan, S., Güher, H., 2005. The rotifera fauna of Gala Lake, Pak J Biol Sci 8(11): 1579-1583.

Güher, H., Kırgız, T., 2007. A study on associated microcrustacea (Cladocera, Copepoda) with macrophytes in Gala Lake National Park. Trakya University. Journal of Sciences 2: 109-114.

Kaya, M., Kurtonur, C., 2003. Investigations on the ornitho-fauna of Gala Lake and its surroundings (Edirne). Trakya University, Journal of Sciences 4: 169-179. ISSN 1302 647X

Kırgız, T., 1988. A preliminary study on Chironomidae (Diptera) larvae from Lake Gala. IX. National Biology Congress. 21-23 September, Sivas. 489-498.

Koskivaara, M., Valtonen, ET., 1992. Dactylogyrus (Monogenea) communities on the gills of roach in three lakes in Central Finland. Parasitology 104: 263-272. doi: $10.1017 /$ S0031182000061709
Eustrongylides excisus was found at a high percentage and mean intensity in perch. Perch are predominantly bottom feeders; tubificids, common benthic animals in the lake, are intermediate hosts for $E$. excisus.

\section{Acknowledgements}

This study was supported by The MarmaraUniversity Scientific Research Community (Project No. FEN-A-0406090171). We sincerely thank 114 . Branch Office of $\left.X\right|^{\text {th }}$ Regional Directorate of State Hydraulic Works, Ipsala-Edirne for providing the research facility.

Madanire-Moyo, G., Barson, M., 2010. Diversity of metazoan parasites of the African catfish Clarias gariepinus (Burchell, 1822) as indicators of pollution in a subtropical African river system. Journal of Helminthology, 84: 216-227. doi: 10.1017/S0022149X09990563

Marcogliese, DJ., 2004. Parasites: small players with crucial roles in the ecological theatre. Ecohealth 1: 151-164. doi: 10.1007/s10393-004-0028-3

Margolis, L., Esch, GW., Holmes, JC., Kuris, AM., Schad, GA., 1982. The use of ecologicalterms in parasitology (Report of an ad hoc committee of the American Society of Parasitologists). Journal of Parasitology 68, 131-133. doi: $10.2307 / 3281335$

Niewiadomska, K., 2003. The parasites of Polish fish (key to species identification) (in Polish). The flukes - Digenea. Warszawa: PTP. $169 \mathrm{p}$

Ortak, R., Kırgız, T., 1988. Gala gölü Cladocera ve Copepoda (Crustacea) Türleri. IX. Ulusal Biyoloji Kongresi. 21-23 Eylül, Sivas. C.2, 377-385.

Overstreet, RM., 1997. Parasitological data as monitors of environmental health. Parassitologia 39: 169-175

Özuluğ, M., Meriç, N., Freyhof, J., 2004. The distribution of Carassius gibelio (Bloch, 1782) (Teleostei: Cyprinidae) in Thrace (Turkey). Zoology in the Middle East 31, 63-66. doi: 10.1080/09397140.2004.10638023

Paperna, I., 1996. Parasites, infections and diseases of fishes in Africa: an update. FAO/CIFA Technical Paper no. 31. Rome, FAO.

Pietrock, M., Meinel,t T., Marcogliese, DJ., Steinberg, CEW., 2001. Influence of aqueous sediment extracts from the Oder River (Germany/Poland) on survival of Diplostomum sp. (Trematoda: Diplostomidae) cercariae. Archives of Environmental Contamination and Toxicology, 40: 327-332. doi: $10.1007 / \mathrm{s} 002440010179$

Poulin, R., 1992. Toxic pollution and parasitism in freshwater fish. Parasitol. Today 8, 58-61. doi: 10.1016/0169-4758(92)90090-0

Pugachev, ON., Gerasev, PI., Gussev, AV., Ergens, R., Khotenowsky, I., 2010. Guide to Monogenoidea of freshwater fish of Palaeartic and Amur regions (scientific editors: O.N. Pugachev, P.Galli, D. Kristsky). 567 pp.

Scholz, T., Drabek, R., Hanzelova, V., 1998. Scolex morphology of Proteocephalus tapeworms (Cestoda: Proteocephalidae), parasites of freshwater fish in the Palaearchtic region. Folia Parasitologica 45: 27-43. doi: 10.1371

Zal, N., 2006. A study on the implementation of lower Meriç Valley flood plain as a biosphere reserve. Ankara University, The Graduate School of Natural and Applied Sciences, Department of Landscape Architecture. Ph.D. Thesis, 195 pp. 